\title{
ЗМІНИ МАКРО- І МІКРОЕЛЕМЕНТНОГО СКЛАДУ ПЕЧІНКИ ЩУРІВ У ДИНАМІЦ РОЗВИТКУ СИНДРОМУ ТРИВАЛОГО СТИСНЕННЯ
}

\section{Зміни макро- і мікроелементного складу печінки щурів у динаміці розвитку синдрому тривалого стиснення}

\section{Т. П. Пилипчук}

Тернопільська обласна дитяча клінічна лікарня

Резюме. Враховуючи високу летальність при тяжких фрормах синдрому тривалого стиснення (СТС), вагоме місце займає вивчення механізмів, що перебігають у динаміці даного патологічного синдрому

Мета дослідження - вивчити в динаміці показники макро- і мікроелементного складу печінки щурів на моделі ендотоксикозу, що формується за умов синдрому тривалого стиснення.

Матеріали і методи. Досліди проведені на 40 безпородних статевозрілих білих щурах-самцях. Експериментальною моделлю слугував патологічний процес, що розвивався у тварин унаслідок стиснення м'яких тканин лівої тазової кінцівки протягом 4-х год у спеціальному пристрої. Площа стискаючої поверхні становила $4 \mathrm{~cm}^{2}$, а сила компресії- 4,25 ка/ $\mathrm{cm}^{2}$. При цьому цілість великих судин і кісткових структур нижньої кінцівки зберігалась. Таким чином, у тварин моделювався синдром тривалого стиснення середнього ступеня. У печінці дослідних тварин визначали рівень макро- та мікроелементів методом атомно-абсорбційної спектрофротометрії на спектрофотометрі C-115 ПК.

Результати. Так, вміст кальцію у печінці підвищувався на 3 добу експерименту на 18,2 \% та залишався вірогідно високим до 14 доби. Разом з тим, рівень магнію зменшувався вже на 1 добу на 19,2 \%, коливаючись у цих межах до 7 доби, а потім знову знижувався на 106,7 \% стосовно контрольної групи. Вміст цинку в печінці поступово зростав 31 доби (на 12,8 \%) до 14 доби (на 34,0 \%) спостереження відносно контролю. Таку ж тенденцію відмічено щодо вмісту купруму, проте його рівень вірогідно підвищувався на 3 добу експерименту.

Висновки. В умовах гіпоксії та оксидативного стресу, що розвиваються в тканинах організму щурів 3 експериментальним синдромом тривалого стиснення, відмічається дисбаланс макро- та мікроелементів, який характеризується підвищенням вмісту кальцію, цинку і купруму та зниження вмісту магнію в печінці тварин.

Ключові слова: синдром тривалого стиснення; кальцій; магній; цинк; купрум; печінка; експеримент.

\section{Changes of macro- and microelement composition of rat liver in the dynamics of crush-syndrome development}

\section{T. P. Pylypchuk}

Ternopil Regional Children's Clinical Hospital

e-mail: taraspulypchuk@gmail.com

Summary. Given the high lethality in severe forms of crush-syndrome, the study of mechanisms in the dynamics of a given pathological syndrome is of great importance.

The aim of the study - to investigate the dynamics of macro- and micronutrient composition of rat liver in a model of endotoxicosis, which is formed under conditions of crushsyndrome.

Materials and Methods. Experiments were conducted on 40 adult white male rats. The experimental model was a pathological process that developed in animals as a result of the compression of the soft tissues of the left pelvic limb for 4 hours in a special device. The area of the compressive surface was $4 \mathrm{~cm}^{2}$, and the force of compression was $4.25 \mathrm{~kg} / \mathrm{cm}^{2}$. At the same time, the integrity of large vessels and bone structures of the lower limb was maintained. Thus, a moderate degree of crushsyndrome was simulated. In the liver of experimental animals, the level of macro- and microelements was determined by atomic absorption spectrophotometry using a C-115 PC spectrophotometer.

Results. Thus, calcium content in the liver increased in $3 r d$ day of experiment by $18.2 \%$ and remained high until 14 days. At the same time, magnesium levels decreased by $19.2 \%$ at first day, fluctuating within these values to 7 th day, and then decreased again by $106.7 \%$ relative to the control group. Zinc content in the liver gradually increased from first day (by $12.8 \%$ ) to 14th day (by $34.0 \%$ ) of the observation relative to control. The same trend was observed for the content of cuprum, but its level probably increased at 3rd day of the experiment.

Conclusions. In conditions of hypoxia and oxidative stress, which develop in the tissues of rats with experimental crush-syndrome, there is an imbalance of macro- and microelements, which is characterized by an increase in calcium, zinc and cuprum content and a decrease in the magnesium content in the liver of animals.

Key words: crush-syndrome; calcium; magnesium; zinc; cuprum; liver; experiment. 


\section{ВСТУП}

Синдром тривалого стиснення (СТС) виникає у результаті фрізичної травми від тривалого стиснення тулуба, кінцівок або інших частин тіла та проявляється комплексом специфічних патологічних процесів, що розвиваються після звільнення травмованої ділянки [1]. Зазначається, що отримане ушкодження м'яких тканин, м'язів та нервів може бути наслідком первинного прямого впливу травми чи ішемії, пов'язаної зі стисненням [2]. У результаті порушення цілості скелетних м'язів у кров і позаклітинний простір вивільняються внутрішньоклітинні м'язові компоненти, включаючи міоглобін, креатинкіназу, альдолазу та лактатдегідрогеназу, а також електроліти. При цьому стан пацієнта залежить від рівня цих метаболітів [3].

СТС займає 15-24 \% у структурі травматичних уражень, розвивається приблизно в 2-5 \% жертв стихійних лих (наприклад землетрусу) та у 10,5 \% жертв фрізичного насилля [4]. Враховуючи високу летальність при тяжких фрормах СТС (приблизно 85-90 \%), вагоме місце займає вивчення механізмів, що перебігають у динаміці даного патологічного синдрому [5].

Метою дослідження було вивчити в динаміці показники макро- і мікроелементного складу печінки щурів на моделі ендотоксикозу, що фрормується за умов синдрому тривалого стиснення.

\section{МАТЕРІАЛИ I МЕТОДИ}

Досліди проведено на 40 безпородних статевозрілих білих щурах-самцях масою тіла 180-200 г, яких поділили на п'ять груп: інтактна група $(\mathrm{n}=8)$, експериментальні групи (1; 3; 7 і 14 доби спостереження) по 8 тварин на кожен термін спостереження.

Вибрані терміни дослідження відповідали загальноприйнятим періодам розвитку синдрому тривалого стиснення: від 1 до 3 діб - ранній період; від 3 до 7 діб - проміжний період; від 7 до 21 доби - пізній (відновний період) [6].

Експерименти проводилися під наркозом, шляхом внутрішньочеревного введення кетаміну гідрохлориду (з розрахунку 100 мг/кг маси тіла). Експериментальною моделлю слугував патологічний процес, що розвивався у тварин унаслідок стиснення м'яких тканин лівої тазової кінцівок протягом 4-х год у спеціальному пристрої, сконструйованому на кафедрі фрункціональної та лабораторної діагностики ДВНЗ «Тернопільський державний медичний університет імені І. Я. Горбачевського МО3 України». Площа стискаючої поверхні становила 4 $\mathrm{cm}^{2}$, а сила компресії - 4,25 кг/см² [7]. При цьому цілість великих судин і кісткових структур нижньої кінцівки зберігалась. Таким чином, у тварин моделювався синдром тривалого стиснення середнього ступеня. Всі маніпуляції з експериментальними тваринами проводили із дотриманням правил відповідно до Європейської конвенції про захист хребетних тварин, що використовуються для дослідних та інших наукових цілей [8].

У печінці дослідних тварин визначали рівень макро- та мікроелементів методом атомно-абсорбційної спектрофротометрії на спектрофротометрі С-115 ПК.

Статистичну обробку цифррових даних здійснювали за допомогою програмного забезпечення Excel (Microsoft, США) та STATISTICA 6.0 (Statsoft, США) 3 використанням непараметричних методів оцінки одержаних даних. Розраховували медіану і квартилі розподілу Ме $\left[\mathrm{Q}_{25}-\mathrm{Q}_{75}\right]$. Достовірність різниці значень між незалежними кількісними величинами визначали за допомогою U-критерію МанаУїтні.

\section{РЕЗУЛЬТАТИ Й ОБГОВОРЕННЯ}

У патогенезі СТС поєднуються різні механізми, включаючи ішемію, ендотоксикоз, запалення, які зумовлюють поліорганні зміни. Не менш важливим пусковим механізмом розвитку патобіохімічних реакцій, що виникають за умов експериментального СТС, на нашу думку, є дисбаланс макро- та мікроелементів. Так, вміст кальцію у печінці підвищувався на 3 добу експерименту на 18,2 \% та залишався вірогідно високим до 14 доби. У той же час, рівень магнію зменшувався вже на 1 добу на 19,2 \%, коливаючись у цих межах до 7 доби, а потім знову знижувався на 106,7 \% стосовно контрольної групи. Варто відмітити, що через 14 діб експерименту рівень магнію був вірогідно нижчий даних на 1; 3 і 7 доби. Відомо, що недостатність магнію супроводжується підвищенням оксидативного стресу 3 одночасним послабленням антиоксидантного захисту [9], що підтверджено результатами нашого попереднього дослідження [1]. Одним 3 механізмів такої різноспрямованої зміни цих двох мікроелементів $є$ розвиток запалення [10], яке розвивається при СТС. Вміст цинку в печінці поступово зростав 31 доби (на 12,8 \%) до 14 доби (на 34,0 \%) спостереження відносно контролю. Таку ж тенденцію відмічено щодо вмісту купруму, проте його рівень вірогідно підвищувався на 3 добу експерименту (на 25,0 \%), тоді як через 14 діб його вміст був вищий на 55,0 \% проти контрольних значень (табл.) Такі зміни цинку і купруму можуть бути пов'язані 3 експресією Zn-, Cu-вмісних супероксиддисмутаз і металотіонеїнів [11]. При надмірному надходженні купруму відбувається підвищення концентрації вільних форм металу в тканинах організму, що веде до активації процесів утворення реакційних гідроксильних радикалів, які токсично впливають на клітинні мембрани, приводячи до їх руйнування [12]. Активуючи тканинні процеси пероксидації ліпідів, купрум веде до орормування структурних змін 


\begin{tabular}{|c|c|c|c|c|c|}
\hline \multirow[b]{2}{*}{ Показник } & \multicolumn{5}{|c|}{ Група тварин } \\
\hline & $\begin{array}{c}\text { контроль } \\
(\mathrm{n}=8)\end{array}$ & $\begin{array}{c}\text { 1-ша доба } \\
(\mathrm{n}=8)\end{array}$ & $\begin{array}{c}\text { 3-я доба } \\
(n=8)\end{array}$ & $\begin{array}{c}\text { 7-ма доба } \\
(\mathrm{n}=8)\end{array}$ & $\begin{array}{c}\text { 14-та доба } \\
(\mathrm{n}=8)\end{array}$ \\
\hline $\begin{array}{l}\text { Кальцій, мг/г } \\
\text { золи }\end{array}$ & $\begin{array}{c}0,27 \\
{[0,23 ; 0,31]}\end{array}$ & $\begin{array}{c}0,29 \\
{[0,28 ; 0,31]}\end{array}$ & $\begin{array}{c}0,33 \\
{[0,32 ; 0,36]} \\
p_{1}<0,05 \\
p_{2}<0,05\end{array}$ & $\begin{array}{c}0,35 \\
{[0,33 ; 0,35]} \\
p_{1}<0,05 \\
p_{2}<0,05\end{array}$ & $\begin{array}{c}0,34 \\
{[0,32 ; 0,38]} \\
p_{1}<0,05 \\
p_{2}<0,05\end{array}$ \\
\hline Магній, мг/г золи & $\begin{array}{c}0,31 \\
{[0,25 ; 0,39]}\end{array}$ & $\begin{array}{c}0,26 \\
{[0,24 ; 0,28]} \\
p_{1}<0,05\end{array}$ & $\begin{array}{c}0,24 \\
{[0,21 ; 0,24]} \\
p_{1}<0,05\end{array}$ & $\begin{array}{c}0,23 \\
{[0,22 ; 0,25]} \\
p_{1}<0,05\end{array}$ & $\begin{array}{c}0,15 \\
{[0,14 ; 0,16]} \\
\mathrm{p}_{1}<0,05 \\
\mathrm{p}_{2}<0,05 \\
\mathrm{p}_{3}<0,05 \\
\mathrm{p}_{4}<0,05\end{array}$ \\
\hline Цинк, мг/г золи & $\begin{array}{c}0,47 \\
{[0,45 ; 0,51]}\end{array}$ & $\begin{array}{c}0,53 \\
{[0,51 ; 0,54]} \\
p_{1}<0,05\end{array}$ & $\begin{array}{c}0,57 \\
{[0,56 ; 0,58]} \\
p_{1}<0,05 \\
p_{2}<0,05\end{array}$ & $\begin{array}{c}0,59 \\
{[0,55 ; 0,60]} \\
p_{1}<0,05 \\
p_{2}<0,05\end{array}$ & $\begin{array}{c}0,63 \\
{[0,62 ; 0,65]} \\
\mathrm{p}_{1}<0,05 \\
\mathrm{p}_{2}<0,05 \\
\mathrm{p}_{3}<0,05 \\
\mathrm{p}_{4}<0,05\end{array}$ \\
\hline $\begin{array}{l}\text { Купрум, мг/г } \\
\text { золи }\end{array}$ & $\begin{array}{c}0,20 \\
{[0,18 ; 0,22]}\end{array}$ & $\begin{array}{c}0,22 \\
{[0,21 ; 0,23]}\end{array}$ & $\begin{array}{c}0,25 \\
{[0,24 ; 0,25]} \\
p_{1}<0,05 \\
p_{2}<0,05\end{array}$ & $\begin{array}{c}0,25 \\
{[0,24 ; 0,26]} \\
p_{1}<0,05 \\
p_{2}<0,05\end{array}$ & $\begin{array}{c}0,31 \\
{[0,28 ; 0,31]} \\
\mathrm{p}_{1}<0,05 \\
\mathrm{p}_{2}<0,05 \\
\mathrm{p}_{3}<0,05 \\
\mathrm{p}_{4}<0,05\end{array}$ \\
\hline
\end{tabular}

Примітка. $p_{1}$ - зміни достовірні відносно показників контрольних тварин; $p_{2}$ - достовірність змін між групою на першу добу спостереження та щурами на третю добу спостереження; $p_{3}$ - достовірність змін між групою на третю добу спостереження та щурами на сьому добу спостереження; $\mathrm{p}_{4}$ - достовірність змін між групою на сьому добу спостереження та щурами на чотирнадцяту добу спостереження.

внутрішніх органів, у тому числі й печінки [13]. Відомо, що металотіонеїни $є$ головними білками, що забезпечують гомеостаз цинку, зв'язують до семи іонів цинку і транспортують іони до апобілків з утворенням металоферментів [14]. За умови СТС у печінці спостерігається надмірна продукція активних форм оксигену, які спричиняють вивільнення цинку з білків, призводячи до його зростання.

\section{СПИСОК ЛІТЕРАТУРИ}

1. Пилипчук Т. П. Особливості вільнорадикального окиснення при експериментальному синдромі тривалого стиснення / Т. П. Пилипчук, І. Я. Криницька, М. І. Марущак // Медична та клінічна хімія. - 2018. - № 4. C. $79-85$.

2. Compartment syndrome: diagnosis, management, and unique concerns in the twenty-first century / M. R. Garner, S. A. Taylor, E. Gausden [et. al.] // HSS J. 2014. - No. 10 (2). - P. 143.

3. Rhabdomyolysis: Pathogenesis, diagnosis, and treatment / P. A. Torres, J. A. Helmstetter, A. M. Kaye [et. al.] // The Ochsner Journal. - 2015. - No. 15. - P. 58-69.

4. Lovallo E. Crush syndrome / E. Lovallo, A. Koyfman, M. Foran // African Journal of Emergency Medicine. - 2012. - No. 2. - P. 117-123.

5. Разработка методики моделирования синдрома длительного сдавления / А. П. Трухан, С. А. Жидков,

\section{висновки}

В умовах гіпоксії та оксидативного стресу, що розвиваються в тканинах організму щурів з експериментальним синдромом тривалого стиснення, відмічається дисбаланс макро- та мікроелементів, який характеризується підвищенням вмісту кальцію, цинку і купруму та зниження вмісту магнію в печінці тварин.

В. Е. Корик [и др.] // Военная медицина. - 2013. - № 3. - C. 105-107.

6. Нечаев Э. А. Синдром длительного сдавления : руководство для врачей / Э. А. Нечаев, А. К. Ревской, Г. Г. Савицкий. - Медицина,1993. - 208 с.

7. Involvement of nitric oxide system in experimental muscle crush injury / I. Rubinstein, Z. Abassi, R. Coleman [et al.] // J. Clin. Invest. - 1998. - Vol. 101 (6). - P. 1325-1333.

8. European convention for the protection of vertebrate animals used for experimental and other scientific purposes. - Council of Europe. Strasbourg. - 1986. - No. 123. - 52 p.

9. Марушко Ю. В. Обґрунтування застосування препаратів магнію в педіатричній практиці : огляд літератури / Ю. В. Марушко, Т. В. Гищак // Современная педиатрия. - 2016. - № 6 (78). - С. 27-32.

10. Вплив дисбалансу мікроелементів на регуляцію апоптозу в щурів з аліментарним ожирінням / М. І. Мару- 
щак, І. В. Антонишин, Г. Г. Габор [та ін.] // Вісник наукових досліджень. - 2015. - № 3. - С. 97-100.

11. Марущак М. І. Експериментальне аліментарне ожиріння: апоптоз, антиоксидантна система, макро- і мікроелементи в тканині печінки / М. І. Марущак, О. П. Мялюк, І. М. Кліщ // Медична та клінічна хімія. 2015. - T. 17, № 4. - С. 29-33.

12. Gaetke L. M. Copper toxicity, oxidative stress, and antioxidant nutrients / L. M. Gaetke, C. K. Chow // Toxicology. - 2003. - No. 1. - P. 147-163.

\section{REFERENCES}

1. Pylypchuk TP, Krynytska IY, Marushchak MI. [Features of free radical oxidation in experimental syndrome of prolonged compression]. Medychna ta klinichna khimiia. 2018;4: 79-85. Ukrainian.

2. Garner MR, Taylor SA, Gausden E, Lyden JP. Compartment syndrome: diagnosis, management, and unique concerns in the twenty-first century. HSS J. 2014;10(2): 143.

3. Torres PA, Helmstetter JA, Kaye AM, Kaye AD. Rhabdomyolysis: Pathogenesis, diagnosis, and treatment. The Ochsner Journal. 2015;15: 58-69.

4. Lovallo E, Koyfman A, Foran M. Crush syndrome. African Journal of Emergency Medicine. 2012;2: 117-23.

5. Truhan AP, Zhidkov SA, Coryk VE, Letkovskaya TA, Zhidkov AS, Tereshko DG. [Development of a technique for modeling the syndrome of prolonged compression]. Voyennaya meditsina. 2013;3: 105-7. Russian.

6. Nechaev EA, Revskoy AK, Savitsky GG. Long-term compression syndrome: A guide for doctors. [Синдром длительного сдавления: руководство для врачей] Moscow: Meditsina; 1993. Russian.

7. Rubinstein I, Abassi Z, Coleman R, Milman F, Winaver J, Better OS. Involvement of nitric oxide system in experimental muscle crush injury. J Clin Invest. 1998;101(6): 1325-33
13. Очеретина Р. Ю. Взаимосвязь морфофрункционального состояния печени с метаболизмом костной ткани / Р. Ю. Очеретина // Успехи современного естествознания. - 2015. - № 2. - С. 89-93.

14. Активність алкогольдегідрогенази та вміст біоелементів у тканинах печінки щурів за умов розвитку алкогольної інтоксикації / І. О. Степанець, А. Г. Кудрявцева, О. І. Харченко [та ін.] // Вісник Харківського національного університету імені В. Н. Каразіна. Серія : Біологія. - 2013. - Вип. 17, № 1056. - С. 30-36.

8. European convention for the protection of vertebrate animals used for experimental and other scientific purposes. Council of Europe. Strasbourg; 1986.

9. Marushko YuV, Gischak TV. [Substantiation of the use of magnesium drugs in pediatric practice (literature review)]. Sovremennaya pediatriya. 2016;6(78): 27-32. Ukrainian.

10. Marushchak MI, Antonyshyn IV, Gabor GG, Brzhiskiy AV. [The influence of microelement imbalance on the regulation of apoptosis in rats with alimentary obesity]. Visnyk naukovykh doslidzhen. 2015;3: 97-100. Ukrainian.

11. Marushchak MI, Myalyuk OP, Klishch IM. [Experimental alimentary obesity: apoptosis, antioxidant system, macro- and microelements in liver tissue]. Medychna ta klinichna khimiia. 2015;4: 29-33. Ukrainian.

12. Gaetke LM, Chow CK. Copper toxicity, oxidative stress, and antioxidant nutrients. Toxicology. 2003;1: 147-63.

13. Ocheretina RYu. [Relationship of the morphofunctional state of the liver with metabolism of bone tissue]. Uspekhi sovremennogo yestestvoznaniya. 2015;2: 89-93. Russian.

14. Stepanets IO, Kudryavtseva AG, Kharchenko OI, Voitenko VV, Ostapchenko LI. [The alcoholdehydrogenase activity and bioelements content in liver of rats under alcohol intoxication development]. Visnyk Kharkiv nats univer. Ser: biol. 2013;17(1056): 30-6. Ukrainian. 